\title{
Fetal bovine serum influences apoptosis and apoptosis-related gene expression in porcine parthenotes developing in vitro
}

\author{
Xiang-Shun Cui, Yu-Jeong Jeong, Hwa-Young Lee, Sun-Hong Cheon and Nam-Hyung Kim \\ Department of Animal Sciences, Research Center for Bioresource and Health, Chungbuk National University, \\ Gaesin-dong, Cheongju, Chungbuk, 361-763, South Korea \\ Correspondence should be addressed to Nam-Hyung Kim; Email: nhkim@chungbuk.ac.kr
}

\begin{abstract}
This study was conducted to determine the effects of polyvinyl alcohol (PVA), fetal bovine serum (FBS) and bovine serum albumin (BSA) on blastocoel formation, total cell number, apoptosis and Bcl-xL and Bak gene expression in porcine presumptive diploid parthenotes developing in vitro. The addition of $0.4 \%$ BSA to the culture medium enhanced the development of 2-cell or late 4-cell stage parthenotes to the blastocyst stage $(P<0.01)$ while FBS decreased the incidence of blastocoel formation. FBS also reduced the frequency of blastocysts developed from both 2 -cell $(P<0.001)$ and late 4-cell $(P<0.05)$ embryos and increased the percentage of blastocysts undergoing apoptosis $(P<0.001)$. The relative abundance of $B c l-x L$ mRNA in presumptive diploid parthenotes in the control, PVA- and BSA-supplemented medium was similar to that of in vivoderived embryos, but was significantly higher than in parthenotes cultured with FBS supplement $(P<0.05)$. Bak mRNA significantly increased at the blastocyst stage in FBS-supplemented cells $(P<0.01)$. These results suggest that apoptosis-related gene expression is significantly affected by FBS, and that this may result in alteration of apoptosis and embryo viability of porcine embryos developing in vitro.

Reproduction (2004) 127 125-130
\end{abstract}

\section{Introduction}

In vitro culture of mammalian embryos has previously involved the use of complex media containing serum or co-culture systems with somatic cells, but these undefined mixtures are confounding, as they add variability and make it difficult or impossible to examine the specific roles of components in cellular processes (Eyestone \& First 1989, Bavister 1995). Replacing serum or somatic cell culture with bovine serum albumin (BSA) as a protein source has generally resulted in superior embryo development (Edwards et al. 1997). Pig embryos can be developed in vitro from the zygote to the blastocyst stage in a simple culture medium containing BSA (Kim \& Menino 1997). Although serum did not support development of porcine 1- to 2-cell stage embryos, serum in the culture medium improved the incidence of hatching for morulae and early blastocysts (Pollard et al. 1995, Koo et al. 1997).

The fertilized mammalian embryos are cleaved under maternal gene expression, usually in the oviduct, and undergo compaction and blastocoel formation under embryonic gene expression in the uterus. In porcine embryos, an in vitro developmental block is frequently observed at the 4-cell stage, a time coincident with major activation of the porcine embryonic genome (Jarrell et al. 1991). Previously, Krisher et al. (1999) demonstrated that bovine embryos developing in vitro display different BSA requirements before and after embryonic genome activation (Gardner et al. 1994). However, it is not clear whether BSA contributes factors which help in blastocoel formation, or whether BSA provides a metabolic substrate which is normally lacking in the culture medium.

Programmed cell death or apoptosis is crucially involved in development and differentiation. Environmental stresses, such as those imposed by in vitro culture, can induce unscheduled apoptosis in cultured embryos, which may lead to arrest or abnormal development and lower viability of embryos (Hardy et al. 1989, Jurisicova et al. 1998, Byrne et al. 1999). Cory and Adams (1998) reported that members of the $\mathrm{Bcl}-2$ gene family play key roles in regulating apoptosis, and at least 15 mammalian $\mathrm{Bcl}-2$ gene family members have been identified. These have been categorized into two subgroups, anti-apoptotic (BCl-2, BCl-w, Bcl-xL, A1, Mcl-1) and pro-apoptotic (Bax, Bak, Box, Bik, Blk, Hrk, BNIP3, Bim, Bad, Bid, Bcl-xS). 
Among the $\mathrm{BCl}-2$ gene family, $\mathrm{BCl}-\mathrm{xL}$ and Bak are known as anti-apoptotic and pro-apoptotic genes, respectively, in the pig (Boise et al. 1993, Jurisicova et al. 1998). Despite the importance of mRNA expression profiles of apoptosisrelated genes in the mammalian embryos under different culture systems, little information relevant to this subject is available.

It is difficult to obtain pig embryos of homogeneous quality due to the relatively high incidence of polyspermy that occurs during in vitro fertilization. Therefore, diploid parthenotes have frequently been used to study early development in the pig (Van Thuan et al. 2002). In the present study, we determined the effects of polyvinyl alcohol (PVA), fetal bovine serum (FBS) and BSA on the developmental ability and apoptosis of porcine 2-cell parthenotes at $24 \mathrm{~h}$ after activation (before embryonic genome activation) and late 4-cell diploid parthenotes at $72 \mathrm{~h}$ after activation (after embryonic genome activation) developing in vitro. We also determined the relative amounts of $\mathrm{BCl}-\mathrm{xL}$ and Bak gene expression in porcine parthenotes developed under similar culture conditions using sensitive semi-quantitative reverse transcriptase-polymerase chain reaction (RT-PCR).

\section{Materials and Methods}

\section{In vitro porcine oocyte maturation and parthenogenesis activation}

Prepubertal porcine ovaries were collected from a local slaughterhouse and transported to the laboratory at $25^{\circ} \mathrm{C}$ in Dulbecco's phosphate-buffered saline (PBS) supplemented with $5.54 \mathrm{mM}$ D-glucose, $0.33 \mathrm{mM}$ sodium pyruvate, $75 \mu \mathrm{g} / \mathrm{ml}$ potassium penicillin $\mathrm{G}$ and $50 \mu \mathrm{g} / \mathrm{ml}$ streptomycin sulphate (mDPBS). Cumulus-oocyte complexes (COC) were aspirated from follicles 3 to $6 \mathrm{~mm}$ in diameter with an 18-gauge needle into a disposable $10 \mathrm{ml}$ syringe. The COC were washed three times with Hepesbuffered Tyrode's medium containing $0.1 \%(\mathrm{w} / \mathrm{v})$ polyvinyl alcohol (Hepes-TL-PVA). Each group of 50 COC was matured in $500 \mu \mathrm{l}$ tissue culture medium (TCM)-199 supplemented with $0.57 \mathrm{mM}$ cysteine (Sigma, St Louis, MO, USA), $10 \mathrm{ng} / \mathrm{ml}$ epidermal growth factor (Sigma), $10 \mathrm{IU} / \mathrm{ml}$ pregnant mare's serum gonadotrophin (Sigma) and $10 \mathrm{IU} / \mathrm{ml}$ human chorionic gonadotrophin (Sigma) under paraffin oil at $39^{\circ} \mathrm{C}$ for $44 \mathrm{~h}$. Following maturation, cumulus cells were removed by pipetting in the presence of $1 \mathrm{mg} / \mathrm{ml}$ hyaluronidase for $2-3 \mathrm{~min}$. For parthenogenetic activation, oocytes with one polar body were activated by two direct pulses of $140 \mathrm{~V} / \mathrm{mm}$ for $50 \mu \mathrm{s}$ in $0.28 \mathrm{~mol}$ mannitol supplemented with $0.1 \mathrm{mmol} \mathrm{MgSO}_{4}$, and $0.05 \mathrm{mmol} \mathrm{CaCl}_{2}$. After $3 \mathrm{~h}$ of culture in North Carolina State University (NCSU)-23 medium containing $7.5 \mu \mathrm{g} / \mathrm{ml}$ cytochalasin B (Sigma), embryos were washed three times in NCSU-23 medium with $0.4 \%$ (w/v) BSA (Sigma, lot no. A-8806) and cultured in the same medium for $24 \mathrm{~h}$ at $39^{\circ} \mathrm{C}$ in an atmosphere of $5 \% \mathrm{CO}_{2}$ and $95 \%$ air.

\section{In vitro embryo production}

Embryos (blastocyst stage) for this study were recovered from two normally cyclic Large White gilts that were 9 months of age and weighed at least $120 \mathrm{~kg}$ at the time of use. Two gilts were inseminated twice during the period of standing oestrus $(\sim 24 \mathrm{~h})$ and embryos were produced at day 5 . The gilts were slaughtered at a local abattoir and the uteri were flushed with modified PBS containing $0.4 \%$ BSA (Sigma, lot A-8806). An average of 11.5 embryos was obtained per gilt. Single embryos were washed and stored at $-70^{\circ} \mathrm{C}$ until RT-PCR analysis.

\section{Terminal deoxynucleotidyl transferase-mediated dUTP nick-end labelling (TUNEL) assay}

Randomly selected blastocysts from each group were washed three times in PBS ( $\mathrm{pH}$ 7.4) containing polyvinylpyrolidone (PVP, $1 \mathrm{mg} / \mathrm{ml}$ ). This was followed by fixation in $3.7 \%$ paraformaldehyde in PBS for $1 \mathrm{~h}$ at room temperature. After fixation, the embryos were washed in PBS/PVP and permeabilized by incubation in $0.3 \%$ Triton $\mathrm{X}-100$ for $1 \mathrm{~h}$. The embryos were then washed twice in PBS/PVP and incubated with fluorescein-conjugated dUTP and the terminal deoxynucleotidyl transferase enzyme (In Sute Cell Death Detection Kit; Roche, Germany) in the dark for $1 \mathrm{~h}$ at $37^{\circ} \mathrm{C}$. After being counterstained with $50 \mu \mathrm{g} / \mathrm{ml}$ RNase A in $40 \mu \mathrm{g} / \mathrm{ml}$ propidium iodide for $1 \mathrm{~h}$ at $37^{\circ} \mathrm{C}$ to label all nuclei, embryos were washed in PBS/PVP, mounted with slight coverslip compression, and examined under an Olympus fluorescence microscope. Each embryo was analysed for the total number of nuclei and the number of TUNEL-labelled nuclei.

\section{Semi-quantitative RT-PCR}

Embryos were cultured (for $24 \mathrm{~h}$ or $72 \mathrm{~h}$ ) in vitro and harvested at the blastocyst stage on day 7 , or were produced in vivo. Single embryos were washed in $\mathrm{Ca}^{2+}$ - and $\mathrm{Mg}^{2+}$ free PBS, snap frozen in liquid nitrogen, and stored at $-70^{\circ} \mathrm{C}$. Messenger RNA was extracted using the Dynabeads mRNA Direct Kit (Dynal Asa, Oslo, Norway) according to the manufacturer's instructions. In all experiments, $\beta$-actin was used as an internal standard. First, standard cDNA synthesis was achieved by reverse transcription of the RNA using random hexamers and the Superscript reverse transcriptase enzyme (Invitrogen Co., Grand Island, NY, USA). The mRNAs of Bcl-xL, Bak and $\beta$-actin species were then detected by RT-PCR with specific primer pairs (Table 1 ) using reagents supplied in a Taq DNA polymerase kit (Takara Korea Biomedical Inc., Seoul, Korea). The PCR products were visualized under ultraviolet light on $1.5 \%$ agarose (Invitrogen Co.) gels in $1 \times \operatorname{TAE}(242 \mathrm{~g} / \mathrm{l}$ of Tris base, $57.1 \mathrm{ml} / \mathrm{l}$ of glacial acetic acid and $100 \mathrm{ml} / \mathrm{l}$ of $0.5 \mathrm{M}$ EDTA (pH 8.0) buffer containing $1 \mu \mathrm{g} / \mathrm{ml}$ ethidium bromide (Sigma). The intensity of each band was assessed by densitometry using an image analysis program (LabWorks; UVP Inc., Upland, CA, 
Table 1 Primer sequences and cycling conditions used in RT-PCR.

\begin{tabular}{|c|c|c|c|c|c|}
\hline Genes & Genbank accession no. & Primer sequence & Position in sequence & $\begin{array}{l}\text { Cycle number/annealing } \\
\text { temperature }\end{array}$ & $\begin{array}{l}\text { Product size } \\
\text { (base pairs) }\end{array}$ \\
\hline$\beta$-actin & U07786 & $\begin{array}{l}\text { 5' ACTACСТСАTGAAGATCCTC } \\
3^{\prime} \text { ATCTCСТTCTGCATCСТGTC }\end{array}$ & $\begin{array}{l}194-213 \\
565-584\end{array}$ & $35 / 55^{\circ} \mathrm{C}$ & 391 \\
\hline Bak & AJ001204 & $\begin{array}{l}5^{\prime} \text { CTAGAACCTAGCAGCACCAT } \\
3^{\prime} \text { CGATCTTGGTGAAGTACTC }\end{array}$ & $\begin{array}{c}46-65 \\
178-196\end{array}$ & $35 / 55^{\circ} \mathrm{C}$ & 151 \\
\hline $\mathrm{BCl}-\mathrm{xL}$ & AF216205 & $\begin{array}{l}\text { 5' GGAGCTGGTGGTTGACTTTC } \\
\text { 3' CTAGGTGGTCATTCAGGTAAGG }\end{array}$ & $\begin{array}{c}30-49 \\
527-547\end{array}$ & $35 / 55^{\circ} \mathrm{C}$ & 518 \\
\hline
\end{tabular}

USA). The relative amount of each mRNA species was calculated by dividing the intensity of the bands by the intensity of the corresponding $\beta$-actin band.

\section{Experimental design and embryo culture}

To obtain embryos of homogeneous quality, good quality 2-cell stage parthenotes were selected $24 \mathrm{~h}$ after activation. The embryos were randomly allocated into experimental groups.

Experiment 1 examined the effect of different protein supplements on the development of porcine parthenotes. Diploid parthenotes were recovered after $24 \mathrm{~h}$ of culture in NCSU-23 medium containing $0.4 \%$ BSA, presumptive 2-cell stage $(24 \mathrm{~h})$ embryos were collected and washed three times in NCSU-23 medium without (control) or with $0.1 \%$ PVA (w/v, P-1763, Sigma), 10\% FBS ( $/ / v, 16140-$ 071, Gibco) or $0.4 \%$ BSA (w/v, A-8806, Sigma) and then randomly cultured in the same medium containing no additive (control), $0.1 \%$ PVA, $10 \%$ FBS or $0.4 \%$ BSA (Fig. 1). The embryos were cultured for 7 days at $39^{\circ} \mathrm{C}$ in $5 \% \mathrm{CO}_{2}$ in air. Another group of embryos was also collected and grouped at the 2-cell stage $(24 \mathrm{~h})$ and were continually cultured in NCSU-23 media containing $0.4 \%$ BSA. On day 3 ( $72 \mathrm{~h}$ ) each was transferred into one of the media described above for the 2-cell stage embryos and cultured for 7 days. On day 7 , development to the blastocyst stage was recorded.

Experiment 2 was conducted to determine the effect of protein supplements on apoptosis and total cell numbers in blastocysts. In vitro-cultured embryos obtained as described in experiment 1 were harvested at the blastocyst stage on day 7 and a TUNEL assay was used to measure apoptosis. Total nuclei numbers in these embryos were also counted.

Experiment 3 evaluated the effect of protein supplements on Bcl-xL and Bak gene expression in the porcine parthenotes and in the in vivo-produced embryos. Presumptive diploid parthenotes, obtained as described in

\begin{tabular}{|c|c|c|c|c|c|c|}
\hline 24 & & $168 \mathrm{~h}$ & 0 & 2 & & $168 \mathrm{~h}$ \\
\hline \multirow{4}{*}{ BSA } & Control & & \multirow[t]{4}{*}{ or } & \multirow{4}{*}{ BSA } & BSA & Control \\
\hline & PVA & & & & BSA & PVA \\
\hline & FBS & & & & BSA & FBS \\
\hline & BSA & & & & BSA & BSA \\
\hline
\end{tabular}

Figure 1 Schematic representation of culture methods (2-cell collection and grouping at $24 \mathrm{~h}$ ). experiment 1 , were harvested at the blastocyst stage on day 7 , washed in PBS and stored at $-70{ }^{\circ} \mathrm{C}$ until RT-PCR analysis.

\section{Statistical analysis}

The scores for blastocyst stage, mean cell number of blastomeres, percentage of apoptosis and relative abundance of gene expression were subjected to analysis of variance using the general linear model (PROC-GLM) in the SAS software program (Anon 1992). Where significant differences in the main effects were detected in each experimental parameter, treatment effects were compared by the least square method. Differences of $P<0.05$ were considered significant.

\section{Results}

\section{Effect of different supplements on the development of parthenotes (experiment 1)}

The developmental rates of porcine parthenotes generated in NCSU-23 culture medium, supplemented with nothing (control), PVA, FBS or BSA are summarized in Fig. 2. There were no differences in the development to the blastocyst stage of embryos cultured in control medium or in the presence of PVA or FBS at day 7 from both the 2cell $(24 \mathrm{~h})$ stage $(35.9 \pm 2.4 \%, 39.3 \pm 2.4 \%, 35.5 \pm 3.1 \%$ respectively) and the 72 -h parthenotes $(45.9 \pm 1.8 \%$, $51.0 \pm 1.8 \%, 45.7 \pm 1.8 \%$ respectively). However, $72-\mathrm{h}$

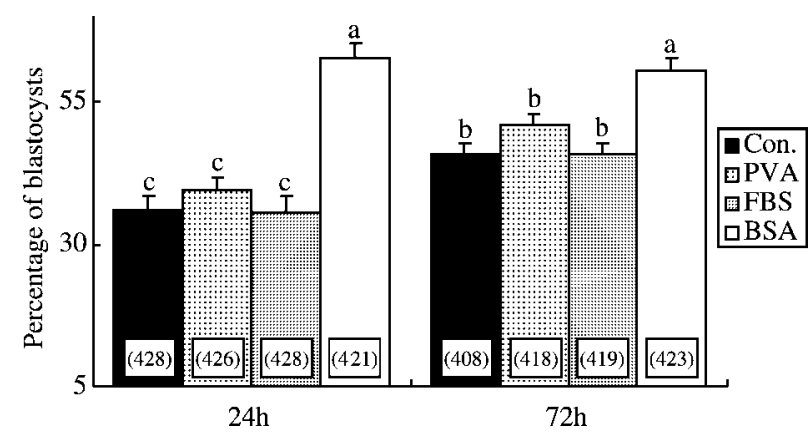

Figure 2 Percentage of 2-cell ( $24 \mathrm{~h}$ ) or late 4-cell ( $72 \mathrm{~h}$ ) stage embryos that developed into blastocysts in NCSU-23 medium supplemented with PVA, FBS or BSA. The number of embryos examined in each experimental group is shown in parentheses. Bars with different letters differ from each other statistically $(P<0.05)$. Con., control. 
cultured parthenotes grown in the presence of BSA were significantly advanced developmentally compared with their counterparts grown in the absence of BSA (control, $P<0.005$; PVA, $P<0.005$; FBS, $P<0.01$ ), with significantly more embryos developing to the blastocyst stage in the BSA group than in its absence from either the 24-h $(65.7 \pm 2.4 \%, \quad P<0.001) \quad$ or $\quad 72-\mathrm{h} \quad(62.6 \pm 1.8 \%$, $P<0.01)$ parthenotes.

\section{Effect of different supplements on cell numbers and apoptosis (experiment 2)}

The results of experiment 2 are presented in Fig. 3. The mean cell number of blastocysts resulting from the control, PVA, and BSA groups did not differ in the 24-h $(41.8 \pm 3.6,43.6 \pm 2.9,45.5 \pm 2.7$ respectively) and $72-$ h $(43.6 \pm 4.67,47.9 \pm 5.18,48.1 \pm 4.92$ respectively) parthenotes cultured. However, in the presence of FBS, total cell number significantly decreased at day 7 (from $24 \mathrm{~h}, 24.9 \pm 2.3, \quad P<0.001$; from $72 \mathrm{~h}, 28.8 \pm 3.2$, $P<0.05)$.

DNA fragmentation resulting from the apoptotic nicking of genomic DNA in individual embryos was measured using the TUNEL assay. Apoptosis did not differ (fragmented cell number/total cell number) in blastocysts of the control and PVA- or BSA-derived embryo groups (from $24 \mathrm{~h}: \quad 4.73 \pm 1.14 \%, \quad 4.46 \pm 0.90 \%, \quad 4.67 \pm 0.99 \%$; from $72 \mathrm{~h}: 4.12 \pm 0.63 \%, 4.29 \pm 0.48 \%, 3.43 \pm 0.56 \%$ respectively; Fig. 4). However, addition of FBS increased the percentage of fragmented cells in embryos cultured from the $24-\mathrm{h} \quad(7.33 \pm 0.65 \%, \quad P<0.05)$ or $72-\mathrm{h}$ (7.01 $\pm 0.63 \%, P<0.01)$ stages.

\section{Effect of different supplements on fragmented cell gene expression (experiment 3)}

To investigate whether protein supplements modulate mRNA expression of apoptotic-related genes in diploid porcine parthenotes developing in vitro and in in vivoderived blastocysts, mRNA was prepared from single

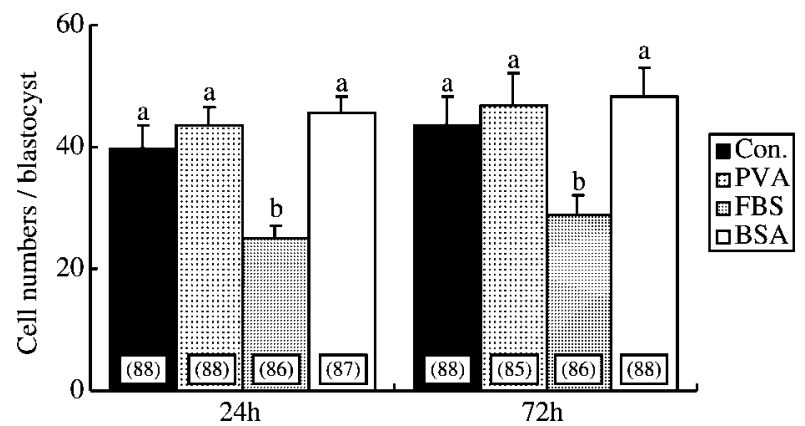

Figure 3 Number of cells per blastocyst at day 7 cultured from 2-cell $(24 \mathrm{~h})$ or late 4 -cell $(72 \mathrm{~h}$ ) stage embryos in NCSU-23 medium supplemented with PVA, FBS or BSA. The number of embryos examined in each experimental group is shown in parentheses. Bars with different letters differ from each other statistically $(P<0.05)$. Con., control.

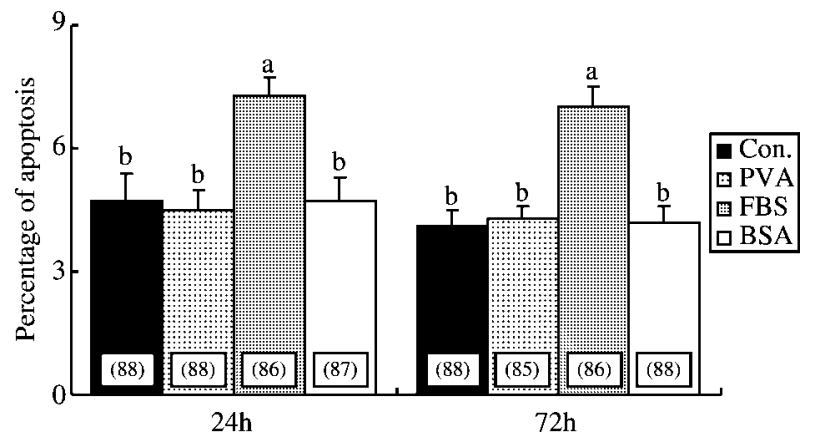

Figure 4 Degree of apoptosis (apoptotic cell no./total cell no.) in blastocysts at day 7 that were cultured from 2 -cell $(24 \mathrm{~h})$ or late 4 -cell (72 h) stage embryos in NCSU-23 medium supplemented with PVA, FBS or BSA. The number of embryos examined in each experimental group is shown in parentheses. Bars with different letters differ from each other statistically $(P<0.05)$. Con., control.

blastocysts cultured in NCSU-23 without or with PVA, FBS or BSA supplementation and was subjected to RT-PCR for Bcl-xL and Bak transcripts (Fig. 5). In the control, PVAand BSA-supplemented media, the relative abundance of $\mathrm{Bcl}-\mathrm{xL}$ mRNA expression was similar to that seen in in vivo-derived blastocysts and was higher than in FBSderived embryos in both the 24-h and 72 -h cultured groups $(P<0.05)$.

There was no difference in Bak mRNA expression in control, PVA, BSA and in vivo-derived embryos, but it was significantly enhanced in FBS-derived embryos from $24 \mathrm{~h}$ $(P<0.005$, Fig. 6) parthenote cultures. In the embryos cultured from the 72-h stage, a similar expression pattern was observed $(P<0.005)$.

\section{Discussion}

In this study, we demonstrated the effects of exogenous protein supplements on porcine blastocyst production. The experiments were performed with embryos of homogeneous quality by selecting good quality porcine diploid parthenotes at the 2-cell stage. We found that porcine presumptive diploid parthenotes, selected at $24 \mathrm{~h}$ and $72 \mathrm{~h}$

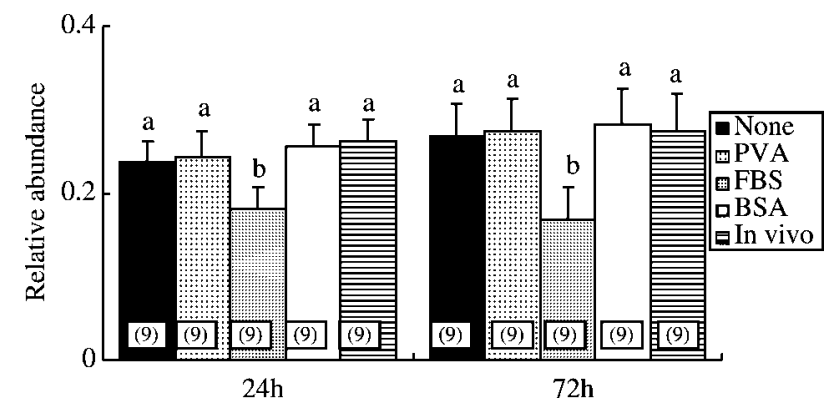

Figure 5 Relative abundance of $\mathrm{Bcl}-\mathrm{xL}$ mRNA expression in porcine parthenotes at day 7 that were cultured from 2-cell $(24 \mathrm{~h})$ or late 4-cell (72 h) stage embryos in NCSU-23 medium supplemented with PVA, FBS or BSA. The number of embryos examined in each experimental group is shown in parentheses. Bars with different letters differ from each other statistically $(P<0.05)$. 


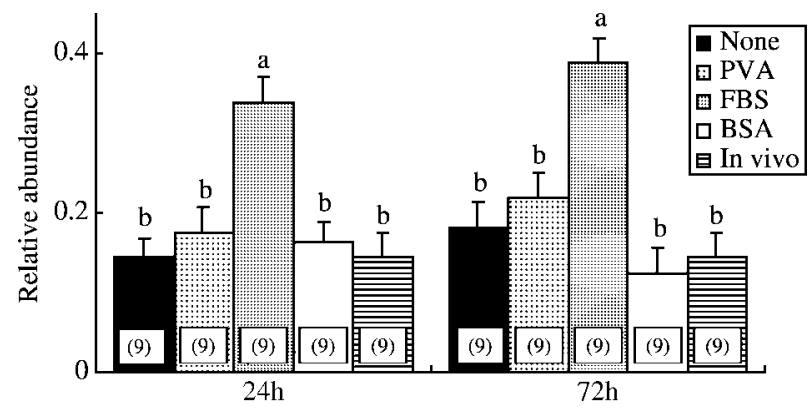

Figure 6 Relative abundance of Bak mRNA expression in porcine parthenotes at day 7 that were cultured from 2-cell $(24 \mathrm{~h})$ or late 4-cell (72 h) stage embryos in NCSU-23 medium supplemented with PVA, FBS or BSA. The number of embryos examined in each experimental group is shown in parentheses. Bars with different letters differ from each other statistically $(P<0.05)$.

after activation, developed to the blastocyst stage at a relatively high rate in the presence of BSA as compared with those in the presence of either PVA or no protein supplements. However, BSA did not increase blastocyst cell numbers. Supplementation of the culture medium with BSA seems to provide beneficial factors such as energy substrates, scavenger ions, unknown growth factors, and other small molecules, as has been suggested previously (Maurer 1992). Krisher et al. (1999) demonstrated that both metabolic activity and blastocyst development of bovine embryos are affected by BSA supplementation. Furthermore, they observed that embryos cultured without BSA in the final stages of culture developed at a lower rate in comparison with those grown without BSA in the initial stages of culture or those cultured continuously with BSA. This suggests that later-stage embryos require more metabolic substrates for their further development. Similarly, we observed that more embryos developed to the blastocyst stage when cultured in the presence of BSA from the initial 72-h period than those cultured from the initial 24-h period. However, it is unclear whether BSA provides the embryos with a metabolic substrate, which is normally lacking in the culture medium, or whether BSA contributes factor(s) to help in blastocoel formation and expansion.

Serum would appear to provide more amino acids, known and unknown growth factors and other macromolecules than does BSA. The presence of serum could promote hatching by providing a pool of plasminogen, which the bovine embryo has been shown to convert to plasmin, that can proteolytically degrade the zona pellucida thereby facilitating hatching (Menino \& Williams 1987). Similarly, in the pig, serum did not support the development of porcine 1- to 2-cell embryos, but improved the incidence of hatching for morulae and early blastocysts (Robl \& Davis 1981, Koo et al. 1997). However, the use of serum for embryo culture produces high variability, making repetition of experiments within and between laboratories difficult. Here, FBS decreased cell numbers in blastocysts cultured from both 24-h and 72-h parthenotes. The ratio of TUNEL-labelled DNA to total DNA of FBSderived blastocysts was significantly greater than for the other treatments ( $7 \%$ vs $4 \%$ ). This result is similar to previous results obtained in cattle. Exposure of early cattle embryos (2- to 8-cell) to FBS significantly reduced the formation of blastocoel and blastocyst cell numbers (Schults et al. 1981, Lawitts \& Biggers 1991, Eckert \& Niemann 1995, Hagemann et al. 1998). Byrne et al. (1999) also reported that a higher apoptotic cell death index was one consequence of culturing 2-cell embryos to blastocysts with serum $(10 \% \mathrm{v} / \mathrm{v})$ instead of albumin $(0.8 \% \mathrm{BSA})$. Collectively, undefined factors in the serum induce apoptosis in early cleavage mammalian embryos, which results in a lower incidence of blastocysts.

Entry to and progression through the apoptotic pathway seem to be controlled by the balanced expression of several conserved genes that have either pro- or antiapoptotic effects. The Bcl-2 gene family is known to include anti-apoptotic and pro-apoptotic subgroups, and the $\mathrm{Bcl}-\mathrm{xL}$ gene functions to protect against apoptosis (Boise et al. 1993). In contrast, another group of highly conserved genes are positive regulators of apoptosis these include the Bak proteins in the pig. In the present study, we found that FBS decreased $\mathrm{BCl}-\mathrm{xL}$ gene expression in blastocysts developing in vitro. This observation may reflect the ability of FBS to reduce the apoptotic process in pig blastocysts. Bcl-xL is a very potent cell death suppressor and in embryos that are destined to develop, increases in the expression of cell death-promoting genes would be inhibited by increasing expression of protective genes (e.g. $\mathrm{Bcl}-\mathrm{xL}$ ) in maternal stores (Jurisicova et al. 1998). Expression of the pro-apoptotic gene, Bak, was higher in blastocysts produced in the presence of FBS than in those produced in its absence or in in vivo-derived embryos. This would be consistent with the notion that mRNA levels for this transcript are higher in inferior-quality embryos. Similarly, Rizos et al. (2003) reported that the presence of serum during the culture period resulted in a significant increase in the level of expression of the pro-apoptotic gene, Bax, in bovine embryos.

In conclusion, our data indicate that supplementing the culture medium with PVA, FBS or BSA influences developmental progression, blastocyst cell numbers and apoptosis. BSA enhanced the in vitro development of porcine diploid parthenotes, while FBS reduced embryo viability. Increasing fragmentation by FBS used in the present experiments not only resulted in reduced blastocyst formation and lower blastocyst cell numbers, but also resulted in decreased expression of the anti-apoptotic gene, $\mathrm{Bcl}-\mathrm{xL}$, and enhanced expression of the pro-apoptotic gene, Bak.

\section{Acknowledgements}

This research is supported by research fund (202113-03-1SB3010) of Agriculture R\&D Promotion Center. 


\section{References}

Anon, SAS Users Guide. Statistics, Cary: Statistical Analysis System Institute, 1992.

Bavister BD 1995 Culture of preimplantation embryos: facts and artifacts. Human Reproduction Update 1 91-148.

Boise LH, Gonzales-Garcia M, Postema CE, Ding LA, Lindsten T, Turka LA, Mao X, Nunez G \& Thompson CB 1993 Bcl-x, a bcl-2 related gene that functions as a dominant regulator of apoptotic cell death. Cell 74 597-608.

Byrne AT, Southgate J, Brison DR \& Leese HJ 1999 Analysis of apoptosis in the preimplantation bovine embryo using TUNEL. Journal of Reproduction and Fertility 117 97-105.

Cory S \& Adams JM 1998 Matters of life and death: programmed cell death at Cold Spring Harbor. Biochimica et Biophysica Acta 1377 R25-R44.

Eckert J \& Niemann H 1995 In vitro maturation, fertilization and culture to blastocysts of bovine oocytes in protein-free media. Theriogenology 43 1211-1225.

Edwards LJ, Batt PA, Gandolfi F \& Gardner DK 1997 Modifications made to culture medium by bovine oviduct epithelial cells: changes to carbohydrates stimulate bovine embryo development. Molecular Reproduction and Development 46 146-154.

Eyestone WH \& First NL 1989 Co-culture of early cattle embryos to the blastocyst stage with oviductal tissue or in conditioned medium. Journal of Reproduction and Fertility 85 715-720.

Gardner DK, Lane M, Spitzer A \& Batt PA 1994 Enhanced rates of cleavage and development for sheep zygotes cultured to the blastocyst stage in vitro in the absence of serum and somatic cells: amino acids, vitamins, and culturing embryos in groups stimulate development. Biology of Reproduction 50 390-400.

Hagemann LJ, Weilert LL, Beaumont SE \& Tervit HR 1998 Development of bovine embryos in single in vitro production (sIVP) systems. Molecular Reproduction and Development 51 143-147.

Hardy K, Handyside AH \& Winston RM 1989 The human blastocyst: cell number, death and allocation during late preimplantation development in vitro. Development 107 597-604.

Jarrell VL, Day BN \& Prather RS 1991 The transcription from maternal to zygotic control of development occurs during the 4-cell stage in the domestic pig, Sus scrofa: quantitative and qualitative aspects of protein synthesis. Biology of Reproduction 44 62-68.

Jurisicova A, Latham KE, Casper RF, Casper RF \& Varmuza SL 1998 Expression and regulation of genes associated with cell death during murine preimplantation embryo development. Molecular Reproduction and Development 51 243-253.

Kim NH \& Menino AR 1997 Effect of different concentration of potassium on pig embryos developing in vitro. Journal of Reproduction and Fertility 111 229-233.

Krisher RL, Lane M \& Bavister BD 1999 Developmental competence and metabolism of bovine embryos cultured in semi-defined and defined culture media. Biology of Reproduction 60 1345-1352.

Koo DG, Kim NH, Lee HT \& Chung KS 1997 Effects of fetal serum, amino acids, vitamins and insulin on the blastocoel formation and hatching of in vivo and IVM/IVF derived porcine embryos developing in vitro. Theriogenology 48 791-802.

Lawitts JA \& Biggers JD 1991 Overcoming the 2-cell block by modifying components in a mouse embryo culture medium. Biology of Reproduction 45 245-251.

Maurer HR 1992 Towards serum-free, chemically defined media for mammalian cell culture. In Animal Cell Culture: A Practical Approach, 2nd edn, pp 15-46. Ed. RI Fresheny. Oxford: Oxford University Press.

Menino AR Jr \& Williams JS 1987 Activation of plasminogen by the early bovine embryo. Biology of Reproduction 36 1289-1295.

Pollard JW, Plante C \& Leibo SP 1995 Comparison of development of pig zygotes and embryos in simple and complex culture media. Journal of Reproduction and Fertility 103 331-337.

Rizos D, Gutierrez-Adan A, Perez-Garnelo S, De La Fuente J, Boland MP \& Lonergan P 2003 Bovine embryo culture in the presence or absence of serum: implications for blastocyst development, cryotolerance, and messenger RNA expression. Biology of Reproduction $68236-243$.

Robl JM \& Davis DL 1981 Effects of serum on swine morulae and blastocysts in vitro. Journal of Animal Science 52 1450-1456.

Schults GA, Kaye PL, McKay DJ \& Johnson MH 1981 Endogenous amino acid pool sizes in mouse eggs and preimplantation embryos. Journal of Reproduction and Fertility 61 387-393.

Van Thuan N, Harayama H \& Miyake M 2002 Characteristics of preimplantational development of porcine parthenogenetic diploids relative to the existence of amino acids in vitro. Biology of Reproduction 67 1688-1698.

Received 17 July 2003

First decision 27 August 2003

Accepted 25 September 2003 